\title{
ANALYTICAL APPLICATIONS OF MEFENAMIC ACID BY HYDROTROPE APPROACH: TITRIMETRIC ESTIMATION AND ULTRAVIOLET METHOD VALIDATION
}

\author{
DEVIKA TRIPATHI ${ }^{1 *}$, DINESH KUMAR SHARMA ${ }^{2}$, JAGANNATH SAHOO ${ }^{3}$ \\ ${ }^{1}$ Department of Pharmacy, Pranveer Singh Institute of Technology, Kanpur, Uttar Pradesh, India. ${ }^{2}$ Department of Pharmacy, Himalayan \\ Institute of Pharmacy, Dehradun, Uttarakhand, India. ${ }^{3}$ Department of Pharmacy, School of Pharmaceutical and Population Health \\ Informatics, Dehradun Institute of Technology University, Dehradun, Uttarakhand, India. Email: tripd990@gmail.com
}

Received: 03 April 2021, Revised and Accepted: 13 May 2021

ABSTRACT

Objectives: Mefenamic acid is used as a modal nonsteroidal anti-inflammatory drug for analytical estimation. Due to the poor aqueous solubility, mefenamic acid liberated reduced bioavailability.

Methods: The hydrotropic solubilization technique is a promising technique used to improve the solubility of water-insoluble drugs. Experimentally, $2 \mathrm{M}$ sodium benzoate has been employed in the prior titrimetric estimation of mefenamic acid and shows synergistic enhancement in the solubility of mefenamic acid by many folds as compared to the distilled water. Similarly, sodium benzoate approach was further applied in analytical estimation of marketed oral dosage forms in tablets, capsules, and suspension for checking the reproducibility of applied approach by ultraviolet (UV) method. Validation of UV method was further done and checked for linearity, accuracy, and precision. Drug degradation studies were also performed successfully to investigate the sustainability of mefenamic acid in various dosage forms under various stress conditions and to establish the preferred storage conditions for the drug.

Results: In the present experimental investigation, obtained mean \% recoveries were close to 100 indicating the accuracy of the proposed approach. Similarly, in analytical estimation of mefenamic acid in oral marketed forms, results have reported lower values of standard deviation, \% coefficient of variation, and standard error facilitated the reproducibility and precision of the proposed approach in the titrimetric estimation and analytical validation of UV method mefenamic acid in bulk and marketed forms.

Conclusion: Therefore, a new, simple, precise, and inexpensive proposed method was executed by validating the result statistically.

Keywords: Hydrotropy, Solubility enhancement, Titrimetric analysis, Ultraviolet method, Development, Validation, Mefenamic acid, Sodium benzoate.

(C) 2021 The Authors. Published by Innovare Academic Sciences Pvt Ltd. This is an open access article under the CC BY license (http://creativecommons.org/ licenses/by/4.0/) DOI: http://dx.doi.org/10.22159/ajpcr.2021v14i7.41682. Journal homepage: https://innovareacademics.in/journals/index.php/ajpcr

\section{INTRODUCTION}

Mefenamic acid as an individual from the anthranilic acid class or fenamates class of nonsteroidal anti-inflammatory drugs used in the treatment of gentle to direct pain and irritation in rheumatic illnesses, osteoarthritis, intense pain like muscle and back pain, toothache, and in menorrhagia. It acts by inhibiting both isoforms of the enzyme cyclooxygenase inhibitors and also focuses on the arrangement of prostaglandins that assume a part in pain affectability and aggravation, fever, additionally in hemostasis, kidney work, pregnancy, and in the assurance of the gastric mucosa [1-5]. As for bioavailability of the BCS Class II drugs, the solubility and dissolution rate are always the rate-determining step and as for mefenamic acid. Thus, the bioavailability problem with BCS Class II drugs thus can be overcome by increasing the solubility and dissolution rate of the drug in the gastrointestinal fluids [2,6-9]. As in this regard, improving the solubility of such drugs, the use of "Hydrotropes" has shown the remarkable ability in improving the bioavailability of mefenamic acid. In general, hydrotropes comprised a hydrophobic part and an ionic moiety responsible for forming the required water-soluble solution. Structure making or breaking phenomenon orients intermolecular hydrogen bonding and thus impacts solution properties, that is, solubility and surface tension. The mechanism of action of hydrotropes is generally based on the minimum concentration of the hydrotrope required to bring the aqueous solubility of the solute, which is related to the volume fraction solubility, the structure of the hydrotrope, and with drug (formed either due to structure breaking and making) and hence a polar group of the hydrotrope, which affects the water depression and the solute interactions [10-14]. A hydrotropic particle collaborates with a less water-dissolvable atom through weak van der Waals cooperation, for example, $\pi-\pi$ or dipole-dipole association. By representing weak van der Waals association and intermolecular hydrogen, authority assists in bringing striking dissolvability and effectiveness of the hydrotrope which dependent on its dissolvability improvement proportion of drug candidate and has an impact on their dissolvable properties. Hydrotrophy includes the utilization of effectively water-dissolvable mixes that assist with blocking the utilization of natural solvents [15-19]. The exploration of the analytical methods for mefenamic acid through titrimetric and ultraviolet (UV) method estimation using hydrotrope is the main objective of the present experiment for the routine analysis of the modal drug. Further, UV method was validated for their reproducible results. Hence, both methods are suggested to apply successfully for routine analysis of the drug.

\section{METHODS [20-29]}

\section{Chemicals and reagents}

Mefenamic acid was supplied as a gift sample by Akums Drugs and Pharmaceuticals Ltd., Raipur, Haridwar. All other chemicals and solvents were used as an analytical grade.

\section{Infrared (IR) spectral studies}

The infrared spectrum of pure mefenamic acid was recorded using Fourier-transform infrared (FTIR) spectroscopy involving neat analysis method. Here, in this method, the sample of drugs spreads on a $\mathrm{KBr}$ plate and pressed under hydraulic pressure. Thus, infrared radiation exposed into the sample and the signals are collected by the detectors 
which sequentially liberated spectra provide the detailed functional groups exhibited in the molecule. Hence, the drug was detected by FTIR in which the spectra are recorded under the wavenumber of $4000 \mathrm{~cm}^{-1}-650 \mathrm{~cm}^{-1}$ which have reported and obtained spectra were also compared with those in official compendia and shown in Fig. 1 and interpretation of IR spectra is mentioned in Table 2.

\section{Preliminary drug solubility estimation}

The equilibrium solubility studies were implemented in a variety of molar solutions of a screened hydrotropic agent. The aqueous solution of sodium benzoate as a hydrotrope was selected and prepared individually at $2 \mathrm{M}$ molar concentration. This agent is accurately measured in their corresponding vial, and thus, an accurate amount of drugs is added and kept in a water bath shaker until a saturated solution is obtained. Then, the prepared solution in the vial was shaken on a water bath shaker for $12 \mathrm{~h}$, allowed to equilibrate for $24 \mathrm{~h}$ to attain equilibrium solubility. The following formula was applied for measuring the solubility enhancement ratio for selected hydrotrope Table 1 :

$$
\text { Enhancement ratio }=\frac{\text { Solubility of drugs in hydrotropic solution }}{\text { Solubility of drugs in distilled water }}
$$

\section{Estimation of mefenamic acid bulk drug by IP method}

For the analysis of Mefenamic acid from official method Indian Pharmacopoeia, drug sample solution was prepared by adding $100 \mathrm{mg}$ of Mefenamic acid into $25 \mathrm{ml}$ of ethanol (95\%) neutralized previously to phenolphthalein as an indicator and final volume was achieved by adding $25 \mathrm{ml}$ of water. It was then titrated with a $0.1 \mathrm{M}$ sodium hydroxide solution. Each $\mathrm{ml}$ of $0.1 \mathrm{M}$ sodium hydroxide is equivalent to $0.02543 \mathrm{~g}$ of $\mathrm{C}_{16} \mathrm{H}_{14} \mathrm{O}_{3}$. Drug content was determined $(\mathrm{n}=3)$ and represented in Table 3.

Estimation of mefenamic acid bulk drug by the proposed method In the proposed method for analysis: Weighed accurately $100 \mathrm{mg}$ of mefenamic acid drug and transferred to a $250 \mathrm{ml}$ conical flask. Twentyfive milliliters of a solution of $2 \mathrm{M}$ sodium benzoate were added and the flask was shaken for about $10 \mathrm{~min}$ to dissolve the drug. $0.1 \mathrm{M}$ sodium hydroxide solution was used to perform titration using phenolphthalein as an indicator. Blank titration was performed for necessary correction. Each $\mathrm{ml}$ of $0.1 \mathrm{M}$ sodium hydroxide is equivalent to $0.02543 \mathrm{~g}$ of $_{16} \mathrm{H}_{14} \mathrm{O}_{3}$. Drug content was determined $(\mathrm{n}=3)$ and presented in Table 3 .

\section{Application of the proposed (hydrotropes sodium benzoate) method}

For the confirmation of utility and feasibility of the proposed method, mefenamic acid was determined in oral dosage forms (tablets, capsules, and suspension). For all samples assayed, the results obtained using official and proposed methods were compared and statistically evaluated $(n=3)$. Each estimated value reported not exceeding any values of the theoretical values, proving no significant difference

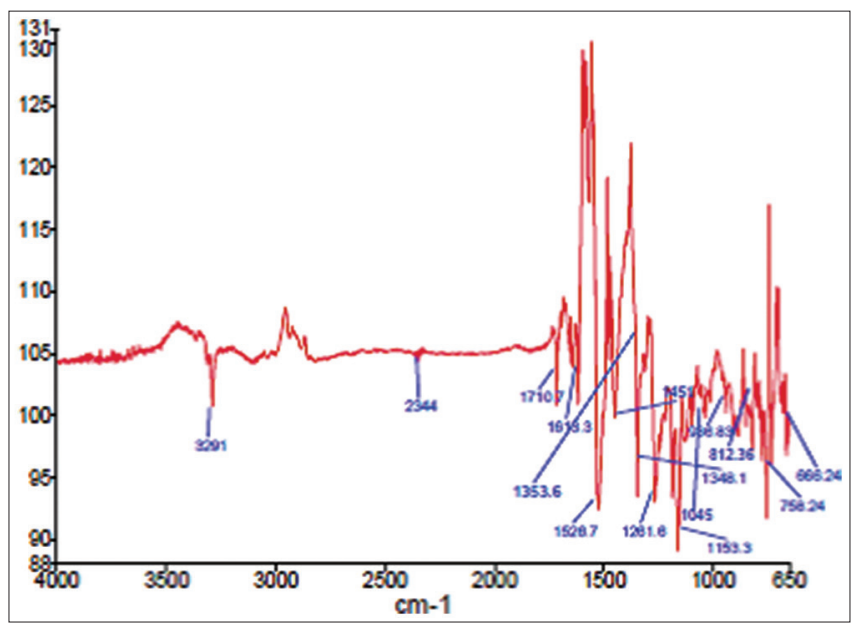

Fig. 1: Fourier transform infrared spectrum of mefenamic acid between applied methods concerning precision and accuracy in the estimation of mefenamic acid in oral dosage forms. Based on estimated recoveries, proposed method was further validated.

Spectrophotometric determination of mefenamic acid in marketed oral dosage forms for routine analysis

Tablets

Five marketed brands of tablets (Ponstan [250 mg], Mefac [250 mg], Mefacid [100 mg and $250 \mathrm{mg}$, Meflup Forte [250 mg], and Flexiwin [100 mg]) were purchased from different medical store located in Kanpur, India. The five brands selected with 5 years shelf life labeled to contain $10 \mathrm{mg}$ per tablet of mefenamic acid.

\section{Standard drug solution}

The solution of $1000 \mu \mathrm{g}$ prepared by transferring accurately weighed $50 \mathrm{mg}$ of mefenamic acid to $100 \mathrm{ml}$ of volumetric flask. For drug solubilization, $40 \mathrm{ml}$ of $2.0 \mathrm{M}$ sodium benzoate was added and final volume was achieved by distilled water and successive shaking for 10$15 \mathrm{~min}$ was performed. Similarly, stock solutions of $100 \mu \mathrm{g} / \mathrm{ml}$ of drug were prepared by dilution method and scanning was done in UV over the range of $400 \mathrm{~nm}-200 \mathrm{~nm}$.

\section{Assay procedure}

Tablets (20) were accurately weighed and powdered. Powdered tablets equivalent to $100 \mathrm{mg}$ were taken and dissolved in $20 \mathrm{~mL} 2 \mathrm{M}$ sodium benzoate solution swirled and sonicated for $2 \mathrm{~min}$. For complete mixing, solution was shaken for $15 \mathrm{~min}$. Filtration of prepared solution was done in Whatman No. 42 filter paper followed by rejecting the first few ml of solutions. The clear supernatant was further used for preparing suitable aliquots followed by dilution sodium benzoate (hydrotropic solution) to get final concentration of $20 \mu \mathrm{g} / \mathrm{mL}$ and corresponding absorbances were measured Table 6.

\section{Capsules}

The different brands (Ponstan, Silaxin) were purchased from different medical store located in Kanpur, India.

The mortar and pestle were used to triturate the capsules of mefenamic acid to convert into powdered form (20 capsules). A powder part equivalent to one capsule weight was dissolved in $2 \mathrm{M}$ sodium benzoate and solution was shaken for $2 \mathrm{~h}$ and sonicated for $15 \mathrm{~min}$ for complete dissolution of solution. The filtrate was diluted by water and a $20 \mu \mathrm{g} / \mathrm{mL}$ solution was prepared. Similar procedure was further applied as used for other formulations for the mefenamic acid content estimation.

Table 1: Preliminary solubility study of mefenamic acid

\begin{tabular}{lllll}
\hline Drug (mg) & $\begin{array}{l}\text { Solvent } \\
\text { system }\end{array}$ & $\begin{array}{l}\text { Solubility } \\
(\% \mathrm{w} / \mathrm{v})\end{array}$ & $\begin{array}{l}\text { Temperature } \\
\left({ }^{\circ} \mathrm{C}\right)\end{array}$ & $\begin{array}{l}\text { Solubility } \\
\text { enhancement } \\
\text { ratio }\end{array}$ \\
\hline $\begin{array}{l}\text { Mefenamic } \\
\text { acid }\end{array}$ & $\begin{array}{l}\text { Distilled } \\
\text { water } \\
2 \mathrm{M} \\
\end{array}$ & 0.12 & $25^{\circ} \mathrm{C}$ & - \\
& $\begin{array}{l}\text { sodium } \\
\text { benzoate }\end{array}$ & & $25^{\circ} \mathrm{C}$ & 76.6 \\
\end{tabular}

Table 2: FTIR spectrum for mefenamic acid identification

\begin{tabular}{llll}
\hline S. No. & $\begin{array}{l}\text { Functional } \\
\text { group }\end{array}$ & $\begin{array}{l}\text { Range } \\
\mathbf{( \mathbf { c m } ^ { - 1 } )}\end{array}$ & $\begin{array}{l}\text { Observed } \\
\text { frequency } \mathbf{( \mathbf { c m } ^ { - 1 } \mathbf { ) }}\end{array}$ \\
\hline 1. & Alkanes & $600-1500$ & 758.24 \\
2. & Aromatic ring & $1500-1600$ & 1528.7 \\
3. & Alcohol & $1000-1300$ & 1261.6 \\
4. & Amines & $3300-3500$ & 3291 \\
5. & Carboxylic acid & $1680-1760$ & 1710.7 \\
\hline
\end{tabular}


Suspensions

One hundred milligrams (Mefmol Suspension) were transferred into a $100 \mathrm{~mL}$ calibrated flask dissolved in $20 \mathrm{~mL} 2 \mathrm{M}$ sodium benzoate followed by sonication same as other formulations.

\section{Mefenamic acid degradation studies}

As per the ICH guidelines, stress studies of mefenamic acid were performed by various stress conditions to observe the effects over wide range of $\mathrm{pH}$, heat, and oxidation, photodegradation, and storage temperature.

\section{Acid degradation}

Twenty milliliters of diluent were used to dissolve $20 \mathrm{mg}$ of mefenamic acid with $10 \mathrm{ml}$ of $1 \mathrm{~N}$ hydrochloric acid ( $1 \mathrm{mg} / \mathrm{ml})$ and refluxed in round bottom flask on boiling water bath for $8 \mathrm{~h}$ ( $25 \mathrm{ml}$ used) followed by keeping the solution at room temperature condition.

\section{Alkali degradation}

To study the effect of alkali degradation, $20 \mathrm{mg}$ of mefenamic acid was dissolved in $20 \mathrm{~m} 1$ of solvent with $10 \mathrm{ml}$ of $0.1 \mathrm{~N} \mathrm{NaOH}(1 \mathrm{mg} / \mathrm{ml})$ followed by refluxing $25 \mathrm{ml}$ of solution in round bottom flask on boiling water bath for $8 \mathrm{~h}$ by keeping solution in room temperature.

\section{Oxidative degradation}

Approximately $10 \mathrm{ml}$ of $30 \% \mathrm{H}_{2} \mathrm{O}_{2} 1 \mathrm{mg} / \mathrm{ml}$ ) was used to dissolve $20 \mathrm{mg}$ of mefenamic acid in $20 \mathrm{ml}$ of diluent to study oxidative stress and refluxed $25 \mathrm{ml}$ of the above solution in round bottom flask on boiling water bath for different time durations, that is, $45 \mathrm{~min}, 2 \mathrm{~h}$, and $6 \mathrm{~h}$.

\section{Photodegradation}

Mefenamic acid (20 mg) was placed in covered Petri dishes as a thin layer and put under the sunlight for different time intervals and for blank observations Petri dishes placed in dark conditions.

\section{Thermal degradation}

By placing $20 \mathrm{mg}$ of mefenamic acid in different weighing bottles and keeping them at $105^{\circ}$ for different time intervals was done to observe the thermal degradation effects on drug.

\section{Storage conditions}

To study the effects of storage conditions on mefenamic acid for the prediction of best storage conditions for the drug, it was placed at room temperature conditions and saved for a day in the refrigerators temperature for several days, that is, 1 day, 7 days, and 14 days. Using IR spectroscopy, the percentage of the active substance was calculated under these circumstances.

\section{Analytical applications and validation of proposed method}

The proposed method was successfully applied for quantitative determination of mefenamic acid in different pharmaceutical preparations and further validated as per ICH guidelines and good recoveries were obtained, as shown in Tables 4 and 7.

\section{Accuracy}

Accuracy of the developed method was checked by scanning in the UV range of $400 \mathrm{~nm}-200 \mathrm{~nm}$. For interference of formulation additives, recovery experiments were carried out by standard addition method $(80,100$, and $120 \mathrm{mg}$ drug). A percentage recovery was calculated from total amount of drug found.

\section{Repeatability precision test}

To check the degree of repeatability of the methods, suitable statistical evaluation was carried out. Five samples of the tablet formulations were analyzed for the repeatability study. The standard deviation coefficient of variance and standard error was calculated.
Precision studies (interday and intraday precision)

The intra- and inter-day precision was calculated by assay of the sample solution on the same day and on different days at different time intervals, respectively.

\section{Recovery study}

The recovery study was also carried out by the addition of different amounts of drugs to pre-analyze solution $(50 \mu \mathrm{g} / \mathrm{ml})$. From the stock solution of $100 \mu \mathrm{g} / \mathrm{ml}$ of each drug, $1 \mathrm{ml}$ solution was taken in each of four volumetric flasks $(10 \mathrm{ml})$, then $1.2,0.8$, and $0.4 \mathrm{ml}$ of mixed standard stock solution $(100 \mu \mathrm{g} / \mathrm{ml}$ of MA) added in three flasks so that remaining one flask contains no added solution and scanned in $285 \mathrm{~nm}$. Good percentage recovery was reported Table 7.

\section{RESULTS AND DISCUSSION}

IR spectral studies

IR spectra confirmed the drug mefenamic acid with observed frequencies.

\section{Preliminary solubility studies of drug}

The enhancement in solubility of 100 -fold was reported for mefenamic acid in hydrotropic mixture solution of $2 \mathrm{M}$ sodium benzoate as compared to solubility in distilled water. The aqueous solubility of pure mefenamic acid in distilled water was $0.012 \% \mathrm{w} / \mathrm{v}$, whereas in $2 \mathrm{M}$ sodium benzoate, the solubility was found to be approximately $9.2 \% \mathrm{w} / \mathrm{v}$. Hence, the stability of mefenamic acid in sodium benzoate solution was evaluated by keeping the solution at room temperature conditions for $24 \mathrm{~h}$ of duration. Further, the proposed method was optimized and UV method was developed for analytical estimation in marketed oral dosage forms.

\section{Degradation study}

In this regard, further study was performed for isolating and characterizing the degradants by exposing to different stress conditions. Susceptibility of mefenamic to acid, alkali, oxidative, thermal, and photolytic degradation in the marketed formulation was investigated. To establish the probable storage conditions for mefenamic acid, storage condition prediction studies were performed by storing the drug in room temperature for the $1^{\text {st }}$ day the reported percentage of active ingredient $100.7 \%$ and similarly under refrigerator condition, the active ingredient percentage was remained same, that is, $100.7 \%$. Consequently, storage condition prediction studies were further continued for next several days to 14 days and the active percentage ingredient reported approximately was $98.7 \%$, in the refrigerator, it was $96.8 \%$. For day 14, the percentage of the active ingredient was found $95.8 \%$ and in the refrigerator condition $91.9 \%$. Thus, it was concluded that temperature has affected the stability of active drug in marketed forms. The suggestive best storage condition for mefenamic acid was at room temperature away from sunlight and moisture Table 5.

\begin{tabular}{lll}
\hline S. No. & Sample & Estimated percentage \\
\hline 1. & Normal & 99.99 \\
2. & Acid & 77.51 \\
3. & Alkali & 93.52 \\
4. & Oxide & 92.21 \\
5. & Heat & 98.86 \\
6. & Sunlight & 100.00 \\
\hline
\end{tabular}

Accuracy and reproducibility of the proposed method were further confirmed by recovery studies. The results of the study confirmed that any little change in the drug concentration in the solution could be possible to estimate by the applied proposed method.

Repeatability results indicated the precision under the same operating conditions over a short interval of time and interassay precisions. Intermediate precision study expresses variation within laboratory conditions in different days. The results of intra- and inter- 
Table 3: Analysis data of bulk drug sample with statistical evaluation $(n=3)$

\begin{tabular}{lllll}
\hline $\begin{array}{l}\text { Amount of } \\
\text { bulk drug } \\
\text { taken } \mathbf{( m g )}\end{array}$ & $\begin{array}{l}\text { Method of } \\
\text { analysis }\end{array}$ & $\begin{array}{l}\text { \% drug } \\
\text { estimated } \\
\text { (Mean } \mathbf{S D} \text { ) }\end{array}$ & $\begin{array}{l}\text { Coefficient of } \\
\text { variation (\%) }\end{array}$ & $\begin{array}{l}\text { Standard } \\
\text { error }\end{array}$ \\
\hline 100 & IPM & $97.29 \pm 0.63$ & 0.647 & 0.368 \\
100 & PTM & $98.26 \pm 0.66$ & 0.671 & 0.383 \\
\hline
\end{tabular}

IPM: Indian Pharmacopoeia method, PTM: Proposed titrimetric method

Table 4: Marketed formulation estimation of mefenamic acid

\begin{tabular}{lllll}
\hline Formulation & $\begin{array}{l}\text { Label } \\
\text { claim } \\
\text { (mg) }\end{array}$ & $\begin{array}{l}\text { Calculated } \\
\text { amount }\end{array}$ & $\begin{array}{l}\text { \% recovery } \\
\text { proposed } \\
\text { method }\end{array}$ & $\begin{array}{l}\text { \% } \\
\text { recovery } \\
\text { reference } \\
\text { method }\end{array}$ \\
\hline Tablets & & & & \\
$\quad$ Mefacid (F1) & 100 & $99.56 \pm 0.5$ & 99.67 & 99.09 \\
$\quad \begin{array}{l}\text { Flexiwin (F2) } \\
\text { Meflup Forte (F3) }\end{array}$ & 250 & $254.5 \pm 0.23$ & $102.16 \pm 1.5$ & 101.96 \\
$\quad$ Mefac (F4) & 250 & $253.8 \pm 0.21$ & $101.52 \pm 0.62$ & 101.68 \\
$\quad \begin{array}{l}\text { Ponstan (F5) } \\
\text { Mefacid (F6) }\end{array}$ & 250 & $252.6 \pm 0.15$ & $100.64 \pm 0.69$ & 100.96 \\
Capsules & 250 & $253.4 \pm 0.51$ & $100.96 \pm 0.42$ & 101.12 \\
$\quad \begin{array}{l}\text { Silaxin Cap.* } \\
\text { Ponstan Cap.* }\end{array}$ & 250 & $253.8 \pm 0.54$ & $100.99 \pm 0.48$ & 101.24 \\
Suspension & 250 & $252.8 \pm 0.17$ & $100.7 \pm 0.72$ & 101.06 \\
Mefmol Susp.* & $5.3 \pm 0.2$ & $10.6 \pm 0.25$ & $5.2 \pm 0.7$ & 104.00 \\
\hline
\end{tabular}

*Susp: Suspension; *Cap: Capsules

Table 5: Stress condition

\begin{tabular}{llll}
\hline Storage temperature conditions & Day 1 & Day 7 & Day 14 \\
\hline $4^{\circ} \mathrm{C}$ & $100.7 \%$ & $96.8 \%$ & $91.9 \%$ \\
$25^{\circ} \mathrm{C}$ & $100.7 \%$ & $98.7 \%$ & $95.8 \%$ \\
\hline
\end{tabular}

Table 6: Analytical parameter

\begin{tabular}{ll}
\hline Parameters & Values \\
\hline Observed, $\lambda \max$ & $285 \mathrm{~nm}$ \\
Beer's range $\mu \mathrm{g} / \mathrm{ml}$ & $5-60$ \\
Slope & 0.0426 \\
Intercept $(\mathrm{c})$ & 0.0038 \\
Correlation coefficient & 0.9899 \\
\hline
\end{tabular}

day precision and intersubject variation study were reported not more than $2.0 \%$ variance reflected good recoveries and results are indicated in Table 8:

Analytical methods comparison (proposed and standard method) Table 9 shows the comparative analysis between fewer analytical parameters of the present method with recent spectrophotometric methods:

\section{DISCUSSION}

The methods developed and discussed in the present work provide a unique, convenient, reproducible, and accurate way for analytical estimation of mefenamic acid in its bulk and pharmaceutical oral dosage form. The results of applied titrimetry approach demonstrated that the mean percent drug content of mefenamic acid in the bulk sample was measured by the standard pharmacopoeial method and found that values were $97.29 \pm 0.63$. Similarly, the proposed method ( 2 M sodium benzoate hydrotrope) was successfully applied for the analysis of bulk drug and $98.26 \pm 0.66$ was found as the mean percent drug content of mefenamic acid. Results of studies have indicated that aqueous solubility of mefenamic acid was appreciatively enhanced in the
Table 7: Recovery studies for the prediction of accuracy

\begin{tabular}{lllll}
\hline Drug & $\begin{array}{l}\text { Label } \\
\text { claim }\end{array}$ & $\begin{array}{l}\text { Amount } \\
\text { added/ } \\
\text { tablet weight }\end{array}$ & $\begin{array}{l}\text { \% } \\
\text { Recovery } \pm \text { SD }\end{array}$ & $\begin{array}{l}\text { Percentage } \\
\text { coefficient } \\
\text { of variance }\end{array}$ \\
\hline F1 & 100 & 80 & 100.02 & 0.221 \\
& & 100 & 98.99 & 0.543 \\
F2 & 100 & 120 & 103.02 & 0.154 \\
& & 100 & 100.28 & 0.253 \\
& & 120 & 101.24 & 0.287 \\
F3 & 100 & 80 & 99.89 & 0.336 \\
& & 100 & 100.15 & 0.165 \\
& & 120 & 99.97 & 0.659 \\
F4 & 100 & 80 & 99.91 & 0.255 \\
& & 100 & 101.05 & 0.876 \\
& & 120 & 98.78 & 0.109 \\
F5 & 100 & 80 & 99.98 & 0.436 \\
& & 100 & 100.07 & 0.245 \\
& & 120 & 99.95 & 0.206 \\
\hline
\end{tabular}

*F1: Formulation 1, *F2: Formulation 2, *F3: Formulation 3,

*F4: Formulation 4, *F5: Formulation 5

Table 8: Repeatability

\begin{tabular}{llllll}
\hline Method & Drug & $\begin{array}{l}\text { Intraday precision } \\
\text { \% coefficient of } \\
\text { variance }(\mathbf{n = 3 )}\end{array}$ & $\begin{array}{l}\text { Interday precision \% } \\
\text { coefficient of variance } \\
\text { (n=3) }\end{array}$ \\
\cline { 3 - 6 } & & & Day 1 & Day 2 & Day 3 \\
\hline F1 & MF & 0.966 & 0.676 & 0.427 & 0.286 \\
F2 & MF & 0.672 & 0.554 & 0.434 & 0.243 \\
F3 & MF & 0.846 & 0.785 & 0.456 & 0.674 \\
F4 & MF & 0.571 & 0.432 & 0.265 & 0.152 \\
F5 & MF & 0.432 & 0.354 & 0.238 & 0.159 \\
\hline
\end{tabular}

MF*: Mefenamic acid

Table 9: Comparative analysis of different methods

\begin{tabular}{lll}
\hline Analytical parameter & Proposed method & Reference method \\
\hline$\lambda \max (\mathrm{nm})$ & 285 & 283 \\
Medium & Aqueous & Non-aqueous \\
Solvent & Water & Organic solvent \\
Beers range & $5-60 \mu \mathrm{g} / \mathrm{mL}$ & $5-25 \mu \mathrm{g} / \mathrm{mL}$ \\
RSD \% & 99.73 & 98.83 \\
Application & Applied for estimation & Used for estimation \\
& of mefenamic acid & of mefenamic acid in \\
& different dosage forms & tablet formulation \\
& tablet, capsule, and in & \\
& suspension & \\
&
\end{tabular}

hydrotropic solution of $2 \mathrm{M}$ sodium benzoate as compared to solubility in distilled water based on analysis done by the proposed method values found to be closed enough of the standard method proving the accuracy of the applied method. Further, for the validation of proposed method, UV spectrophotometry method was applied and developed for the analytical estimations of mefenamic acid in different marketed oral dosage forms. Wavelength of $285 \mathrm{~nm}$ was selected as absorbance maxima of mefenamic acid analysis. Linearity range 5-60 $\mu \mathrm{g} / \mathrm{ml}$ was shown for the analysis. The \% RSD for repeatability $(n=3)$, intraday and interday $(n=3)$ precision was found to be $<2 \%$ indicating the precision of method. Similarly, for the accuracy of proposed method, recovery studies were carried out and the results were found within the range of $99 \%$ and $100 \%$ with lower values of standard deviation and coefficient of variation. Further, the prediction of storage conditions and stress conditions was performed for active drug in marketed formulations. The mefenamic acid was best stored at room temperature away from 
sunlight and moisture whereas the drug was found to be susceptible to acid, alkali, oxidation, and heat conditions.

\section{CONCLUSION}

Hence, the proposed method is effortless, unique, acceptable, reproducible, and environment support. Evidently, from the applied approach, no interference of drug was reported with $2 \mathrm{M}$ sodium benzoate in analytical estimation at $285 \mathrm{~nm}$, hence an attempt could be manifested for analytical estimation of poorly aqueous soluble drugs having $\lambda$ max above $250 \mathrm{~nm}$ by proposed approach provided their preliminary solubility studies confirm the enhancement of solubility in $2 \mathrm{M}$ sodium benzoate. As it is found to be cheaper than most of the organic solvents and thus suggested as a better substitute for expensive organic solvents. Thus, therefore it is concluded that proposed method can save much time and money hence, suggested to be applied in small laboratories for routine analysis of drugs.

\section{ACKNOWLEDGMENT}

The authors are thankful to Akums Drugs and Pharmaceuticals Ltd., Haridwar, for supplying mefenamic acid as a gift sample.

\section{AUTHORS' CONTRIBUTIONS}

Dr. Dinesh Kumar Sharma and Dr. Jagannath Sahoo have investigated and supervised the findings of this presented experiment. Ms. Devika Tripathi carried out all the experimental work and wrote the manuscript with support of Dr. Dinesh Kumar Sharma and Dr. Jagannath Sahoo. All authors discussed the results and contributed to the final manuscript.

\section{AUTHORS' FUNDING}

None.

\section{CONFLICTS OF INTEREST}

The authors declare no conflicts of interest.

\section{REFERENCES}

1. Waghmare A, Taware G, Baokar S, Undare S. Ecofriendly validated spectrophotometric method for the estimation of amlodipine besylate by using hydrotropic solubilization method. Asian J Pharm Anal 2019;9:8-10.

2. Government of India, Ministry of Health and Family Welfare. Indian Pharmacopoeia. Vol. 1, 3. Ghaziabad: Government of India, Ministry of Health and Family Welfare; 2014. p. 194-2429.

3. Bernard S, Mathew M, SenthilKumar KL. Spectrophotometric method of estimation of amlodipine besylate using hydrotropic solubilization. J Appl Pharm Sci 2011;1:177-80.

4. Muhammad AS, Syed FA, Khan MF, Ahmed S, Ahmad I. Formulations of amlodipine: A review. J Pharm 2016;4:1-11.

5. Varma BR, Jampana PK, Rao S. UV spectroscopic method for estimation of amlodipine besylate in tablets. Int J Pharm Chem Bio Sci 2014;4:69-73

6. Biyani R, Yadav KS. Development and validation of UVspectrophotometric method for estimation of irbesartan by the hydrotrophy technique. J Appl Spectrosc 2019;86:1-10.

7. Venkata GK, Koteswara Rao GS, Kalyani G, Sirisha CG. Hydrotropic technique: A promising method to enhance aqueous solubility of nimesulide and to reduce difficulties in bioavailability. Asian J Pharm 2018;12:1-17.

8. John MB, John HB. Wilson and Gisvolds Textbook of Organic Medicinal and Pharmaceutical Chemistry. $12^{\text {th }}$ ed. United States: Lippincott Williams and Wilkins; 2011. p. 626-30.

9. Singh G, Kumar D, Sharma D, Singh M, Kaur S. Q-absorbance ratio spectrophotometric method for the simultaneous estimation of prednisolone and 5-amino salicylic acid in tablet dosage form. J Appl Pharm Sci 2012;2:222-6.

10. Deshmukh VV, Wagh DD, Vassa SP, Gujar KN. Development of first order derivative ultra violet spectrophotometric method for simultaneous estimation of levocetirizine hydrochloride and phenylephrine hydrochloride in bulk and combined dosage form. Int Res J Pharm 2013;4:115-9.

11. Maheshwari RK, Jain S, Padria A, Mulani P, Baghel JS, Maheshwari N. Eco-friendly extraction using solids-a novel application of mixed solvency concept. J Drug Deliv Ther 2019;9:244-9.

12. Rajput AP, Gore RP. N-acylation in non-aqueous medium method of amide synthesis in non-peptide compounds. Scholars Res Lib 2011;3:409-18.

13. Tari A, Padmavathi PP, Das P. Analytical method development and validation of metformin hydrochloride and benfotiamine in bulk and marketed formulations. Saudi J Med Pharm Sci 2017;3:1322-9.

14. Chaudhari SP, Tawani K, Mahaparale PR. Development and validation of UV spectrophotometric method for simultaneous estimation of tramadol hydrochloride and quercetin in niosomes formulation. Scholar Res Lib 2015;7:205-10.

15. Patil SG, Jadhav VM, Kadam VJ. Development and validation of UV spectrometric method for simultaneous estimation of gallic acid and piperine in herbal formulation. World J Pharma Pharm Sci 2014;3:948-56.

16. Rananavare SB, Salunkhe VR. Development and validation of UV spectrophotometric method for simultaneous estimation of montelukast sodium and olopatadine hydrochloride in bulk and formulated dosage form. Int J Pharm Res Dev 2013;5:83-7.

17. Durga K, Sunil D, Roy RK, Sarita K, Hemant K, Prabhat J. Novel UV Spectrophotometer methods for quantitative estimation of concensi (amlodipine 10mg and celecoxib 200mg) using hydrotropic solubilizing agents. J Drug Deliv Ther 2019;9:651-5.

18. Vinnakota SN, Deveswaran R, Bharath S, Basavaraj BV, Madhavan V. Application of mixed hydrotropic solubilization in spectrophotometric estimation of aceclofenac in tablets. J Curr Pharm Res 2011;1:223-6.

19. Gurumurthy V, Deveswaran R, Bharath S, Basavaraj BV, Madhavan V. Application of hydrotropic solubilization in simultaneous estimation of atenolol and amlodipine besylate. Asian J Res Chem 2012;5:57-60.

20. Nagaraj YS. Nagaraj TS, Bharathi DR, Mahantesha MK, Manjunatha TO. Formulation and evaluation of parenteral dosage form of lornoxicam using hydrotropic solubilization method. Am J Pharm Tech Res 2012;2:573-85.

21. Banerjee T, Banerjee B, Jain P, Shukla G, BanerjeeA. Spectrophotometric estimation of lornoxicam and paracetamol tablet dosage form using hydrotropic solubilizing agent. Int J Chem Tech Res 2012;4:232-9.

22. Maheshwari RK, Rathore A, Agrawal A, Gupta MA. New spectrophotometric estimation of indomethacin capsules with niacinamide as hydrotropic solubilizing agent. Pharm Methods 2011;2:184-8.

23. Sherje AP, Desai KJ. Spectrophotometric determination of poorly water soluble drug rosiglitazone using hydrotropic solubilization technique. Indian J Pharm Sci 2011;73:579-82.

24. Nwodo NJ, Nnadi CO, Nnadi KI. Development and validation of novel hydrotropic solubilization method for spectrophotometric determination of halofantrine in pure and solid dosage form. Scholars Acad J Pharm 2013;2:298-303.

25. Dhumal BR, Bhusari KP, Tajne MR, Ghante MH, Jain NS. Stability indicating method for the determination of mefenamic acid in pharmaceutical formulations by HPLC. J Appl Pharm Sci 2014;4:60-4.

26. Raza A. Spectrophotometric determination of mefenamic acidin pharmaceutical preparations. J Anal Chem 2008;63:244-7.

27. Nabeel S, Othman L, Awadis S. Spectrophotometric determination of mefenamic acid in pharmaceutical preparations via arsenazo III-cerium (III) reaction. J Raf Sci 2009;20:8-21.

28. Alarfaj NA, Altamimi SA, Almarshady LZ. Spectrophotometric determination of mefenamic acid in pharmaceutical preparations. Asian J Chem 2009;21:217-6.

29. Singh H, Kumar R, Singh P. Development of UV spectrophotometric method for estimation of mefenamic acid in bulk and pharmaceutical dosage forms. Int J Pharm Pharma Sci 2011;3:237-8. 